\title{
TO EVALUTE THE PERFORMANCE OF VCRS SYSTEM BY COMPARING LESSER SUPERHEATED REFRIGERANT(R-134A) TO HIGHER SUPERHEATED REFRIGERANT (R143A)
}

\author{
Rahul Wandra1*,Taliv Hussain2, Jagannath Verma 3,Arjun Sharma4,Gourav Roy5 \\ Department of Mechanical Engineering, \\ Lovely Professional University Phagwara, \\ Punjab (India) -144402 \\ Email:rahul.17901@1pu.co.in \\ Email:taliv.17727@1pu.co.in
}

\begin{abstract}
Starting from the era of refrigeration and air conditioning system, superheating continuous to be conspicuous topic in basic refrigeration system. In a conventional cooling system refrigerant superheating inside the system is majorly responsible for maximum energy losses. In this paper we have concentrated on the more accurate approach of effect of refrigerant superheating on refrigeration effect of modified vapour compression system and further investigate the work input in compressor and volumetric efficiency. By undertaking different configuration and different models of compressor it is well evaluated that compressor plays a big role in refrigerant superheat losses where superheat is not only responsible for compression losses but also effects positively on refrigeration effect .Experimental results show that the COP of simple vapour compression system with lesser superheated refrigerant is 3.5 where as the COP of vapour compression system with higher superheated refrigerant is 3.17 by varying different ambient air conditions. VCRS having more superheated refrigerant $R-134 a$ decreases coefficient of performance (COP) by $9.4 \%$ and this paper will give us the clear evidence that what would be the required conditions that can fulfill our control over COP.
\end{abstract}

\section{Keyword: COP, VCRS, Superheating.}

\section{INTRODUCTION}

Refrigeration is a technology which absorbs heat at low temperature and provides temperature below the surrounding by rejecting heat to the surrounding at higher temperature. In a refrigerator heat is continuously pump from lower temperature to higher temperature. According to second law it can be possible only with aid of external work done. The substance which works in a system to extract heat from a cold body and to deliver it in a hot body is known as refrigerant. Here in our study R-134a refrigerant is of our interest. Vapour compression refrigeration cycle is an improved type of air refrigeration cycle. It consists of four main components like condenser, compressor, evaporator and expansion valve. Here in this paper we will analyses the effect of change in operating Condition like superheating on the performance of the vapour Compression cycle. Superheating or boiling delay is the phenomenon in which liquid is heated to a higher temperature then its standard boiling point without actual boiling. Main objective of our study is to know superheating effect on refrigeration effect, work input, coefficient of performance and
Volumetric efficiency of compressor in presence or R-134a as a refrigerant.

\section{LITERATURE SURVEY}

Domanski and McLinden [1992] presented simulation results showing different relative rankings of refrigerants studied depending on the cycle used for performance comparison (1lslhx or reversed Rankine cycle).Goswami et al. [1993] employed an evaporative cooling on existing 2.5 Ton Trane Heat Pump by using four media pad of cellulose bound cardboard structures around the outdoor placed condenser. The thickness of the media was $20.32 \mathrm{~cm}$. They reported electric energy saving of $20 \%$ for the retrofitted system when ambient temperature was $34^{\circ} \mathrm{C}$.Yueming.Li et al. [2009] developed the special simulation module for water-cooled VRF based on the Energy Plus's codes, and using manufacturer's performance parameters and data. He embedded that simulation module in the software of Energy Plus. After modeling and testing the new module, on the basis of a typical office building in Shanghai with water-cooled VRF system, the monthly and seasonal cooling energy consumption and the breakdown of the total power consumption were analyzed. The simulation results showed that, during the whole cooling period, the fancoil plus fresh air (FPFA) system consumed about $20 \%$ more power than the water-cooled VRF VRF system and the aircooled VRF system was performed too. All of these provided designers some ideas to analyze the energy features of this new system and then to determine a better scheme of the air conditioning system..Pongsakorm et al. [2013] modelled and experimentally studied the performance of an inverter air conditioner with evaporative cooled condenser. For 1 Ton refrigeration, $15 \mathrm{~cm}$ thickness of cellulose media pad was used. At lower frequency range, COP observed was maximum.

\section{EXPERIMENTAL SETUP}

In this project our main focus concentrated on the air conditioner i.e. Superheated VCRS by employing external source of superheater and Less superheated cycle. It was seen that performance of the refrigerator can be further analysed by introducing superheating system in between the outlet of 


\section{Asia Pacific Journals}

evaporator and inlet of compressor and this is done by installing external superheater. In case of less superheated cycle system air cooled condenser has been used generally right now. The experimental setup consists of a single stage vapour compression system with the basic components i.e. evaporator, compressor, expansion device, condensers and a external super heater source. The coil type heat exchanger has been attached in series after condenser and parallel to the suction line before compressor. The shifting of air cooled air conditioning system to the subcooled i.e.(system with heat exchanger) air conditioning system is done with the help of the system of hand set valve attached. The whole experiment is carried out on R134a (tetra flouroethane) which is used as refrigerant in setup.

After taking the desired numerical figure of reading systemize. system with superheating ,and then we perform the same experiment with air cooled condenser.

Ammeter and voltmeter are used to measure the electrical current and voltage of input power respectively. The bourdon pressure gauges are used to measure the suction(inlet) and discharge(outlet) pressure of compressor. Temperatures of refrigerant and the ambient air at different points are measured by use of RTD PT100 type thermocouples. Before temperature measurement, the surface of the tubes are polished for removing any type of dust or rust and then the thermocouples are laid down onto the surface. Insulation tapes are wrapped around the copper tubes to prevent any heat losses to ambient air.

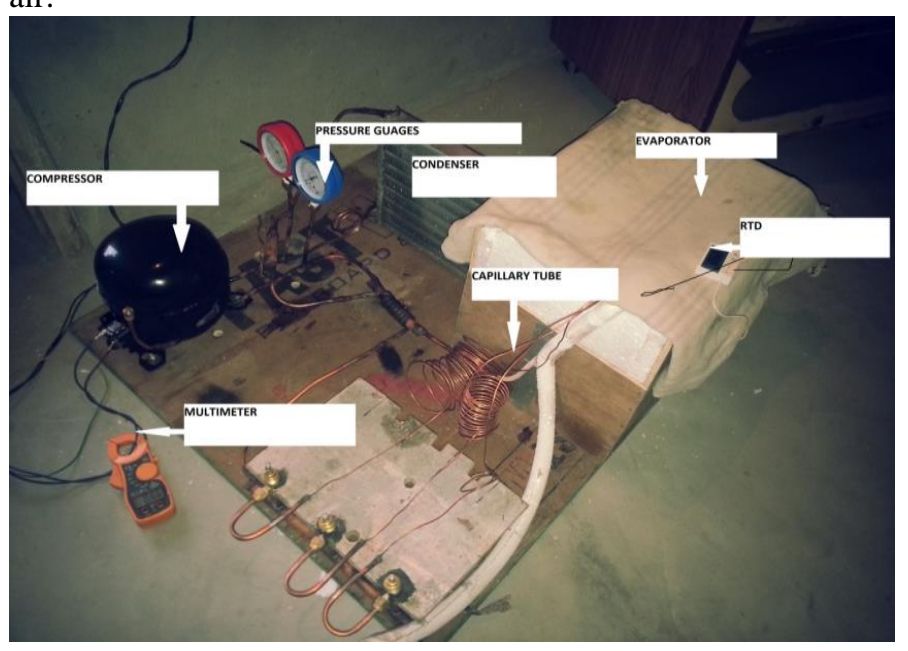

EXPERIMENTAL RESULT OF DIFFERENT AMBIENT TEMPERATURES
ELK Asia Pacific Journals - Special Issue

ISBN: 978-81-930411-4-7

\begin{tabular}{|c|c|c|l|c|}
\hline \multicolumn{5}{|c|}{ Ambient Air Conditions : DBT - 28 ${ }^{\circ} \mathrm{C}$} \\
\hline Parameters & Symbol & Unit & $\begin{array}{l}\text { Less } \\
\text { superheated } \\
\text { cycle }\end{array}$ & $\begin{array}{l}\text { High } \\
\text { superheated } \\
\text { cycle }\end{array}$ \\
\hline $\begin{array}{c}\text { Evaporator } \\
\text { absolute } \\
\text { Pressure }\end{array}$ & $\mathrm{P}_{\text {eva }}$ & bar & 3.48 & 10.1 \\
\hline $\begin{array}{c}\text { Condenser } \\
\text { absolute } \\
\text { Pressure }\end{array}$ & $\mathrm{P}_{\text {con }}$ & Bar & 13.98 & 10.4 \\
\hline $\begin{array}{c}\text { Evaporator } \\
\text { exit } \\
\text { Temperature }\end{array}$ & $\mathrm{T}_{1}$ & ${ }^{\circ} \mathrm{C}$ & 10 & 10 \\
\hline $\begin{array}{c}\text { Compressor } \\
\text { exit } \\
\text { Temperature }\end{array}$ & $\mathrm{T}_{2}$ & ${ }^{\circ} \mathrm{C}$ & 57 & 80 \\
\hline $\begin{array}{c}\text { Condenser } \\
\text { exit } \\
\text { Temperature }\end{array}$ & $\mathrm{T}_{3}$ & ${ }^{\circ} \mathrm{C}$ & 42 & 16.64 \\
\hline $\begin{array}{c}\text { Total electric } \\
\text { current }\end{array}$ & $\mathrm{I}$ & Ampere & 1.4 & 2.12 \\
\hline $\begin{array}{c}\text { Total electric } \\
\text { voltage }\end{array}$ & $\mathrm{V}$ & Volt & 225 & 225 \\
\hline
\end{tabular}

\begin{tabular}{|c|c|c|c|c|}
\hline \multicolumn{5}{|c|}{ Ambient Air Conditions : DBT - $33^{\circ} \mathrm{C}$} \\
\hline Parameters & Symbol & Unit & $\begin{array}{l}\text { Less } \\
\text { superheatedr }\end{array}$ & $\begin{array}{c}\text { High } \\
\text { superheated } \\
\text { VCRS }\end{array}$ \\
\hline $\begin{array}{c}\text { Evaporator } \\
\text { absolute } \\
\text { Pressure }\end{array}$ & $\mathrm{P}_{\text {eva }}$ & Bar & 0.98 & 0.157 \\
\hline $\begin{array}{c}\text { Condenser } \\
\text { absolute } \\
\text { Pressure }\end{array}$ & $\mathrm{P}_{\text {con }}$ & Bar & 9.8 & 1.0166 \\
\hline $\begin{array}{c}\text { Evaporator } \\
\text { exit } \\
\text { Temperature }\end{array}$ & $\mathrm{T}_{1}$ & ${ }^{\circ} \mathrm{C}$ & -18 & 15 \\
\hline $\begin{array}{c}\text { Compressor } \\
\text { exit } \\
\text { Temperature }\end{array}$ & $\mathrm{T}_{2}$ & ${ }^{\circ} \mathrm{C}$ & 41 & 80 \\
\hline $\begin{array}{c}\text { Condenser } \\
\text { exit } \\
\text { Temperature }\end{array}$ & $\mathrm{T}_{3}$ & ${ }^{\circ} \mathrm{C}$ & -18 & 40 \\
\hline $\begin{array}{c}\text { Total } \\
\text { electric } \\
\text { current }\end{array}$ & $\mathrm{I}$ & Ampere & 1.911 & 2.533 \\
\hline $\begin{array}{c}\text { Total } \\
\text { electric } \\
\text { voltage }\end{array}$ & $\mathrm{V}$ & Volt & 225 & 225 \\
\hline
\end{tabular}




\section{ELK Asia Pacific Journals - Special Issue \\ ISBN: 978-81-930411-4-7}

\section{Asia Pacific Journals}

Chart for comparison of $\mathrm{COP}$ and compressor work for two different cycles on the basis of two different ambient temperatures.

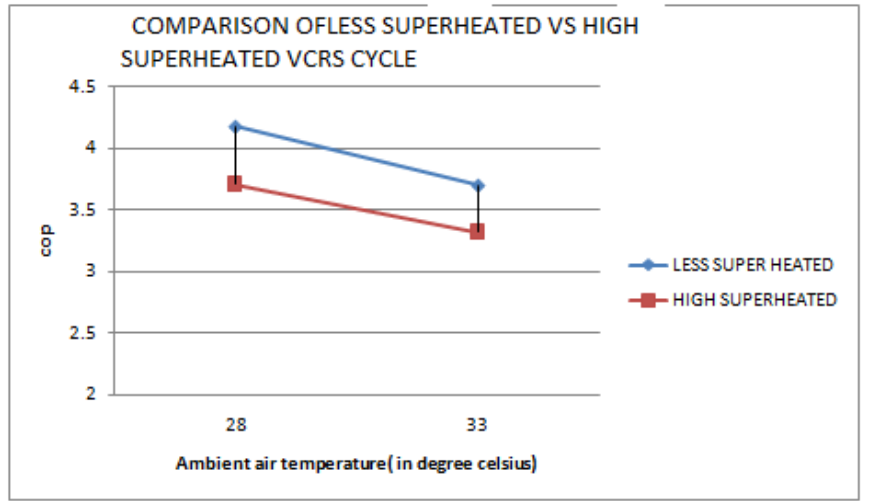

Her we have two different cycles one is highly super heated and second cycle is less superheated VCRS cycle. After visualizing the chart we can easily able to analyses the fact that with increase of ambient temperature no doubt COP will gradually decrease and also with respect to less superheated cycle superheated cycle decreases more then later cycle.

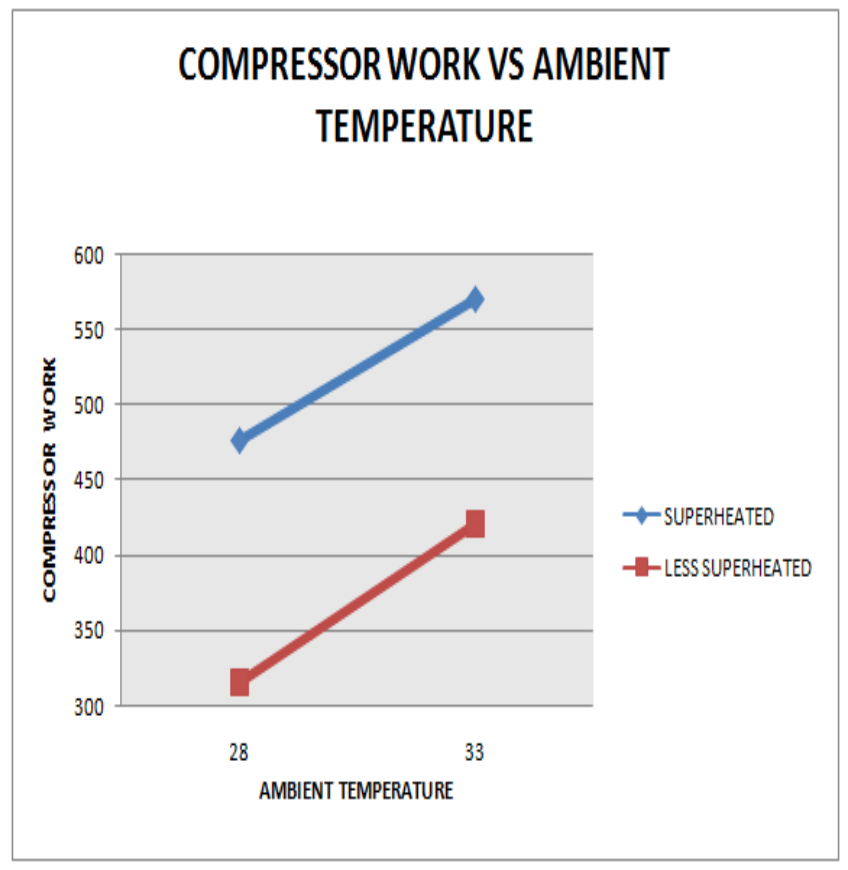

Here in this chart we are comparing two cycles one is highly superheated and other is less superheated . we plot this chart on the basis of different ambient temperature .Its easily visualize us in this graph that less superheated cycle attain high coefficient of performance where as high superheated cycle contains less coefficient of performance.

\section{PH CHART COMPARISON OF TWO VCRS CYCLES}

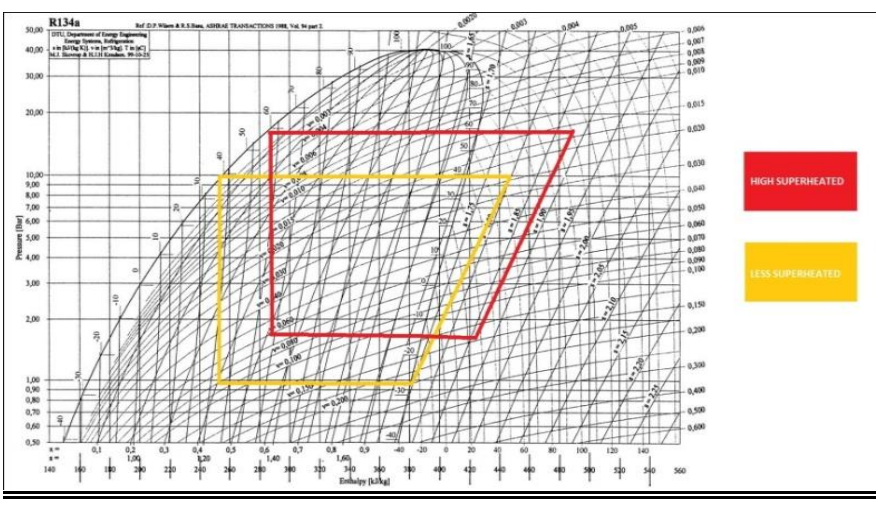

EXPERIMENTAL RESULTS AND DISCUSSIONS

Here in this research paper our group member job was to identify the effect of superheated VCRS system i.e system with external superheating and non superheated VCRS i.e. air cooled refrigeration system or less superheated cycle .Here we have also comparing the results of both superheated VCRS system and less superheated cycle, experimental tests are performed consecutively in two stages. During our first stage of experiment, less superheated cycle is being operated and so that we will be able to get some valuable numeric figure, in the second stage superheated VCRS system is used under the same ambient conditions. Data are not recorded rapidly but its taken after a steady state condition is achieved in the system so

\begin{tabular}{|l|c|c|l|l|}
\hline \multicolumn{5}{|l|}{ Performance Results of Air Conditioner $\left(\mathbf{T}_{\mathrm{amb}}-\mathbf{2 8}^{\circ} \mathbf{C}\right)$} \\
\hline Parameter & Unit & $\begin{array}{l}\text { Less } \\
\text { superheated } \\
\text { cycle }\end{array}$ & $\begin{array}{l}\text { superheatedV } \\
\text { CRS }\end{array}$ & $\begin{array}{l}\text { Variation( } \\
\text { \%) }\end{array}$ \\
\hline $\begin{array}{l}\text { Compressor } \\
\text { Work, } \mathrm{W}_{\mathrm{c}}\end{array}$ & Watt & 315 & 477 & $51.4 \%$ \\
\hline $\begin{array}{l}\text { Coefficient of } \\
\text { performance } \\
(\mathrm{COP})\end{array}$ & & 4.18 & 3.71 & $-11.2 \%$ \\
\hline
\end{tabular}




\section{ELK Asia Pacific Journals - Special Issue}

ISBN: 978-81-930411-4-7

3 shows the results obtained from the observations recorded at three different ambient air temperature i.e. $28^{\circ} \mathrm{C}$ and $33^{\circ} \mathrm{C}$

\section{CONCLUSION}

In this experiment a superheated VCRS with heat exchanger and air simple air cooled VCRS is experimentally investigated. Experimental results show that there is considerable decrease in the COP of the superheated VCRS as compare to air cooled VCRS and further there is significant increase in compressor work for superheated vcrs system as compared air cooled vcrs. In case of superheated VCRS there is decrease in the steady state COP from 3.7 to 3.32 under the following conditions: the wet-bulb temperature is $21^{\circ} \mathrm{C}$, dry-bulb temperature is $29^{\circ} \mathrm{C}$, air velocity is $2.4 \mathrm{~m} / \mathrm{s}$ and power consumption is increased by $29 \%$ whereas as COP decrease by $10 \%$. The experimental investigation also verifies that compressing temperat0ure and pressure increases in case of superheated VCRS system which increases the compressor work. The superheated VCRS system thus results in increasing refrigeration effects and increasing power consumption of the compressor which consequently lead to loss of energy. Thus the use of superheated system with superheater will increase the peak load conditions of power network in extreme hot weather conditions because vapour compression air conditioners are the main cause of peak loads At last it can be well concluded that with high superheating, we can greatly increases the refrigeration effect ,hence ultimately cooling effect of refrigeration but at the same time work required in compressor is also increased and which consumes higher power then less superheated VCR cycle and also this research paper can easily visualize us that in case of high superheated cycle coefficient of performance of refrigeration decreases gradually with increase in ambient temperature.

b. Mass flow rate of refrigerant $m_{r e f}=\frac{\text { Wc }}{(h 2-h 1)}$

c. Cooling effect produced $\mathrm{Qr}=m_{\text {ref }} *(\mathrm{~h} 1-\mathrm{h} 4)$

d. $\mathrm{COP}=\frac{\mathrm{QT}_{\mathrm{T}}}{\mathrm{Wc}_{\mathrm{C}}}$

\section{REFERENCES}

[1] Pramod Kumar (2002) "Finite time thermodynamic analysis of refrigeration and air conditioning and heat pump systems" $\mathrm{PhD}$ thesis, Indian Institute of Technology, Delhi, N D. Arora, C.P. (2010),

$\mathrm{h} 1$ = enthalpy of refrigerant at inlet of compressor in $\mathrm{kj} / \mathrm{kg}(1)$

$\mathrm{h} 2=$ enthalpy of refrigerant at exit of compressor in $\mathrm{kj} / \mathrm{kg} \mathrm{(2)}$

$\mathrm{h} 3=$ enthalpy of refrigerant at exit of the condenser $\mathrm{kj} / \mathrm{kg}$ (3)

h4 = enthalpy of refrigerant at entry of evaporator in $\mathrm{kj} / \mathrm{kg} \mathrm{(4)}$

The voltage and ampere of the input power are obtained from the voltage meter and ampere meter attached in the experimental set-up. Using this voltage and ampere reading, work done of the compressor is obtained Table 1,2 and

[2]"Refrigeration and Air conditioning", 3rd edition, Tata McGraw Hill, New Delhi

[3] A.S. Dalkilic , S. Wongwises,"a performance comparison of vapour compression refrigeration system using various alternative refrigerants" Int. Commun. Heat Mass Transf. ,735-1935 


\section{Asia Pacific Journals}

[ 4] J. Chen, J. Yu, Performance of new refrigerant cycle using refrigerant mixture R32/ R134a for residential air-conditioner applications, Energy and Buildings 40 (2008) 2022-2027.

[5] Klein, S. A., 2010. Engineering Equation SolverLemmon EL, McLinden MO, Huber ML, 2002,

\section{[6] REFPROP 7.0, NIST, USA}

[7] ISI CODE for testing refrigerators no. 1476-1979

[8] Gosney W B, The maximum coefficient of performance of a refrigerant ,paper 2.74, XII international congress of refrigeration, Madrid,1967.

[9] ASHRAE , handbook of fundamentals, 1973

[10] S. Pongsakorn, S. Thepa, 2013, "Modeling and experimental study on the performance of an inverter air conditioner using R-410A with evaporative cooled condenser", Applied Thermal Engineering, 51, 597-610. 